\title{
Editorial \\ Foreword to the special volume on "Mineralogical, geochemical and iso- topic links between granitic pegmatites and their parental granites"
}

This special issue of Journal of Geosciences contains several papers drawing attention to the genetic, spatial and temporal relationships of granitic pegmatites and related granites - one of the paramount problems of granitic pegmatite genesis.

Wise and Brown address the granite-pegmatite link at the famous Sebago system, southern Maine, USA. The authors show mineralogical, petrological and geochemical data that suggest that pegmatitic leucogranites are the likely parent to most LCT granitic pegmatites in this region, although another fertile granite-pegmatite system may be responsible for some anomalous pegmatite dikes showing NYF affinity. Swanson and Veal describe relationships between pegmatites and host granitoids in the high-pressure (0.7-1.1 GPa) Spruce Pine district, North Carolina, USA. They focus on the textural transition from granitoids to pegmatites and argue that the transition was controlled mainly by different nucleation rates as related to water content of the melts. Colombo et al. focus on mineralogy and crystal chemistry of micas from the A-type El Portezuelo granite and related miarolitic pegmatites at Catamarca, northwestern Argentina. The micas (biotite, muscovite, zinnwaldite) exhibit compositional evolution characteristic of NYF-type granitemiarolitic pegmatite systems. Beal and Lentz present detailed mineralogical and isotopic study of aquamarine beryl in A-type pegmatite-aplite dykes and associated quartz veins and greisen at the Zealand Station Be-Mo deposit, New Brunswick, Canada. High $\delta^{18} \mathrm{O}$ values of quartz and beryl indicate a considerable crustal component to the magmas and low $\delta \mathrm{D}$ values of the channel water in beryl reflect crystallization from a volatile-undersaturated magmatic source before pegmatite dyke emplacement. Uher et al. describe primary and secondary compositional trends in beryl in LCT pegmatites of the beryl-columbite subtype in western Carpathians, Slovakia. In the primary trend, Cs, Cs/ $\mathrm{Na}$, $\mathrm{Mg}$ and $\mathrm{Mg} / \mathrm{Fe}$ decrease in most beryl crystals from less evolved to more fractionated pegmatites. In the secondary trend, there is decreasing $\mathrm{Cs}$ and increasing $\mathrm{Mg} / \mathrm{Fe}$ that may represent a late replacement.

These contributions demonstrate the complexity of granite-pegmatite links through mineralogical, geochemical and isotopic data and field relationships. The papers enhance our understanding of the processes that lead to the links.

The guest editors wish to thank the Editor of Journal of Geosciences for supporting this special issue and the reviewers for their diligent efforts in improving the papers. This special issue is dedicated to the scientific session "From gemstones to cell phones: the importance of pegmatites to society" and related field trip "Granitic pegmatites and mineralogical museums in Czech Republic" that are organized on the occasion of the $20^{\text {th }}$ General Meeting of the International Mineralogical Association in Budapest.

\author{
Milan Novák $k^{l}$ and Peter Nábělek ${ }^{2}$ \\ ${ }^{1}$ Masaryk University, Brno, Czech Republic \\ ${ }^{2}$ University of Missouri, Columbia, Missouri, USA
}

[Guest Editors] 
